\title{
PEMBERDAYAAN MASYARAKAT MELALUI PENERAPAN PENGEMBANGAN DESA LOK BAINTAN LEWAT INOVASI ECENG GONDOK MENJADI KERTAS KREASI
}

\author{
Muzahid Akbar Hayat, Sanusi, dan Khuzaini \\ Magister Ilmu Komunikasi, Universitas Islam Kalimantan Muhammad Arsyad Al Banjari \\ E-mail: m.akbarhayat@gmail.com
}

\begin{abstract}
ABSTRAK. Permasalahan utama yang dihadapi Desa wisata Lok Baintan, Kecamatan Sungai Tabuk, Kabupaten Banjar adalah banyaknya tumbuhan eceng gondok yang mengganggu transportasi sungai dan merusak keindahan sungai. Peserta sudah dapat membuat kertas dari eceng gondok, namun dalam prosesnya terhambat saat penjemuran karena bergantung pada matahari. Tujuan dari dilaksanakannya program ini adalah untuk menyelesaikan permasalahan mitra yaitu mampu membuat kertas maupun kreasi tanpa bergantung pada matahari pada saat penjemuran, membentuk manajemen produksi yang baik serta pemasaran yang tepat sasaran. Metode dari program ini adalah dengan menggunakan pendekatan: (a) diskusi group, dengan dua kelompok yaitu kelompok karang taruna dan Pemberdayaan Kesejahteraan Perempuan serta membuka kesempatan masyarakat lain untuk dapar ikut program ini; (b) melakukan Pendidikan dan pelatihan pengolahan eceng gondok menjadi kertas kreasi; (c) desiminasi teknologi oven kertas kreasi; (d) melakukan manajemen produksi dan pemasaran. Hasil dari Program Pengembangan Desa Lok Baintan adalah: (a) meningkatnya peserta hingga $75 \%$ dari peserta yang ada; (b) peserta mampu berinovasi mengolah eceng gondok menjadi kreasi kertas seperti hiasan dinding, lukisan, tempat alat tulis, kota tisu, kupu-kupu, dan buku catatan; (c) peserta manpu menggunakan teknologi oven dalam mengeringkan kreasi kertas sehingga tidak tergantung pada matahari dalam proses penjemuran; (d) peserta mampu memasarkan produk hasil kertas kreasi dari eceng gondok.
\end{abstract}

Kata kunci: pemberdayaan masyarakat; eceng gondok; kertas kreasi; oven pengering kertas kreasi

ABSTRACT. The main problem at tourist village, Lok Baintan, Sungai Tabuk, Banjar is many growth water hyacinth that bother transport and ruin the river beauty. Participants are able to make paper from water hyacinth, but in the process they are hampered by drying because they depend on the sun. The purpose of implementing this program is to solve partner problems, namely being able to make paper or creations without depending on the sun during drying, forming good production management and marketing. The method of this program are to use the following approach: (a) group discussion, with two groups, Karang Taruna and PKK; (b) conduct education and training in processing water hyacinth into creative paper; (c) dissemination of creative paper oven technology; (d) perform production and marketing management. The results of the Lok Baintan Village Development Program are: (a) an increase in participants to 75\% of the existing participants; (b) participants are able to innovate to process water hyacinth into paper creations such as wall hangings, paintings, stationery holders, tissue city, butterflies, and notebooks; (c) manpu participants use oven technology in drying paper creations so that they do not depend on the sun in the drying process; (d) participants are able to market their paper products made from water hyacinth.

Key words: community empowerment; water hyacinth; creative paper; dry oven for paper creation

\section{PENDAHULUAN}

Sungai di Desa Lok Baintan, Kecamatan Sungai Tabuk, Kabupaten Banjar merupakan desa yang dilewati hamparan sungai Martapura. Kondisi geografis desa Lok Baintan memiliki perairan yang luas dan Panjang. Sungai tersebut merupakan lalu lintas utama Desa untuk beraktifitas sehari-hari. Namun sungai tersebut dipenuhi Eceng gondok yang menghambat transportasi juga merusak keindahan sungai mengingat Lok Baintan merupakan desa wisata dengan Pasar Terapung yang mendunia.

Enceng gondok merupakan gulma yang tumbuh di wilayah perairan yang hidup terapung pada air yang dalam atau mengembangkan perakaran di dalam lumpur pada air yang dangkal. Tanaman ini telah menyebar ke seluruh perairan yang ada, baik waduk, rawa, maupun sungai di perairan Jawa, sumatera, Kalimantan dan daerah lainnya (Suprapti, 2008).

Kesadaran masyarakat terhadap pengelolaan sungai masih belum optimal sehingga kehadiran Program Pengembangan Desa Mitra (PPDM) bermitra dengan Karang Taruna dan Pemberdayaan Kesejahteraan Perempuan (PKK) mengolah eceng gondok menjadi kertas kereasi.

Proses pengolahan eceng gondok menjadi kertas sudah dilakukan sejak tahun 2019 melalui program yang sama dengan tujuan masyarakat memiliki pengetahuan dan keterampilah mengolah eceng gondok menjadi kertas. Tahun 2020 menuntut masyarakat atau peserta untuk bisa lebih berinovasi berkreasi menggunakan kertas eceng gondok digabung dengan sampah lain seperti botol plastik, sampah kardus, dan sampah kertas. Selain memproduksi masyarakat dituntut mampu melakukan penjualan produk hasil kertas kreasi eceng gondok. 
Kesadaran masyarakat terhadap pengelolaan sungai khususnya pengelolaan eceng gondok merupakan hal yang sangat penting dan mendesak karenamerupakan permasalahan prioritas. serangan gulma berupa eceng gondok menjadi gangguan serius, Eceng gondok larut di atas air kadang kala menumpuk di lokasi tertentu dan menyita hampir separuh sungai, dan bahkan beberapa kali tumpukannya nyangkut di dua jembatan terbesar kota ini, Jembatan Antasari dan Jembatan Pasar Lama. Nyangkutnya tumpukan eceng gondok beberapa waktu lalu pernah menggunung peraktis menuputi sungai dan mamatikan angkutan air di kawasan tersebut.

Wali Kota Banjarmasin, Ibnu Sina mengatakan sudah melakukan koordinasi dengan Pemprov Kalsel. Pemko kewalahan jika harus bekerja sendiri.

"Eceng gondok ini kiriman dari bagian hulu sungai. Karena Banjarmasin posisinya di hilir, jadi selalu kebagian sampahnya," ucapnya.

Yang Ibnu maksud, daerah lain yang dilewati aliran sungai juga mesti turun tangan. Contohnya seperti Kabupaten Banjar salah satunya adalah Desa Lok Baintan. Nyatanya yang terbawa arus bukan hanya tanaman eceng gondok, melainkan juga berbagai jenis sampah seperti plastik, hingga batang kayu.

Program Pengembangan Desa Mitra dari Kementerian Riset, Teknologi / Badan Riset Dan Inovasi Nasional melalui Pemberdayaan Masyarakat Peduli Lingkungan Desa Sahabat Sampah dirancang untuk menyelesaikan permasalahan mitra perihal pengelolaan eceng gondok dengan mengedepankan konsep ekonomi kreatif keberlanjutan. Penelitian Rodríguez-pose \& Lee (2013) menunjukkan bahwa kreatifitas merupakan pendorong inovasi yang mendasar.

Tahun 2019 Kegiatan pemanfaatan eceng gondok diolah menjadi kertas, dan tahun 2020 kertas dari eceng gondok ditingkatkan kualitasnya dengan berinovasi kertas eceng gondok menjadi karya kreasi bernilai jual tinggi. Selain kreativitas, penelitian Brem, et al. (2016), Sutapa et al. (2017) dan Suparman \& Ruswanti (2017) membuktikan bahwa inovasi merupakan kunci keunggulan bersaing. Hasil penelitian Suparman \& Ruswanti (2017) menunjukkan bahwa inovasi produk berpengaruh baik secara langsung maupun tidak langsung terhadap kinerja industri kreatif yang dimediasi oleh keunggulan bersaing. Program ini merupakan lanjutan dalam rangka mengatasi maraknya eceng gondok di sungai, menambah keindahan dan menjadi Desa Sahabat Sampah Sentra Kreasi Eceng Gondok.
Eceng gondok digunakan sebagai bahan utama dalam pembuatan kertas lalu dikreasikan dengan dikombinasikan sampah botol plastik, sampah kardus, dan sampah kertas. Berdasarkan hasil wawancara dengan ketua kelompok Pemberdayaan Kesejahteraan Keluarga (PKK) Herna Rusnawati menuturkan.

"masyarakat sangat bersemangat membuat kertas dari eceng gondok, karena hasilnya bisa dijual. Masalahnya saat penjemuran kita sangat bergantung pada matahari, banyak kertas gagal jadi karena saat penjemuran terjadi hujan atau tidak ada matahari”

Proses penjemuran saat produksi kertas kreasi, manajemen produksi dan pemasaran menjadi masalah utama mitra. Tujuan dari program ini adalah (1) meningkatkan jumlah peserta hingga $75 \%$; (2) mendidik dan melatih peserta berinovasi mengolah eceng gondok menjadi kertas kreasi; (3) mampu menggunakan oven sebagai pengganti penjemuran menggunakan matahari; dan (4) memiliki manajemen produksi dan mampu memasarkan produk.

\section{METODE}

Kegiatan Pengabdian Kepada Masyarakat program Pengembangan Desa Mitra dilakukan di rumah Kepala Desa Lok Baintan, Kecamatan Sungai Tabuk, Kabupaten Banjar, Provinsi Kalimantan Selatan.

1. Diskusi Kelompok Terarah

Diskusi Kelompok Terarah yang lebih terkenal dengan Focus Group Discussion (FGD) merupakan salah satu metode riset kualitatif yang paling terkenal selain teknik wawancara. FGD adalah diskusi terfokus dari suatu group untuk membahas suatu masalah tertentu, dalam suasana informal dan santai. FGD secara sederhana dapat didefinisikan sebagai suatu diskusi yang dilakukan secara sistematis dan terarah mengenai suatu isu atau masalah tertentu. Irwanto (2006: 1-2) mendefinisikan FGD adalah suatu proses pengumpulan data dan informasi yang sistematis mengenai suatu permasalahan tertentu yang sangat spesifik melalui diskusi kelompok. Diskusi Kelompok Terarah dilakukan di kediaman Kepala Desa Lok Baintan yang diikuti oleh undangan, tokoh masyarakat, PKK dan Karang Taruna.

2. Pemberdayaan

Menurut Widjaja (2003:169) pemberdayaan masyarakat adalah upaya meningkatkan kemampuan dan potensi yang dimiliki masyarakat sehingga masyarakat dapat mewujudkan jati diri harkat dan martabatnya secara maksimal untuk 
bertahan dan mengembangkan diri secara mandiri baik di bidang ekonomi, sosial, agama dan budaya. Pemberdayaan masyarakat adalah sebuah proses dalam bingkai usaha memperkuat apa yang lazim disebut community self-reliance atau kemandirian (Huraerah, 2008:87). Dalam program ini masyarakat didampingi untuk membuat analisis masalah yang dihadapi, dibantu untuk menemukan alternatif solusi masalah tersebut, diberikan pengetahuan dan keteranpilan serta diperlihatkan strategi memanfaatkan berbagai kemampuan yang dimiliki.

3. Pendidikan dan Pelatihan Berkelanjutan

Pelatihan kontinum relationship dilaksanakan dengan mengumpulkan pemuda karang taruna dan Ibu PKK. Tahap awal pelatihan kontinum relationship adalah sosialisasi program. Sosialisasi diberikan kepada karang taruna dan anggota PKK. Selanjutnya, peserta diberikan kegiatan pelatihan. Pelatih dilakukan dengan menghadirkan narasumber yang telah memiliki pengalaman dan pakar dibidang pengolahan sampah/limbah kertas dan plastik untuk memberikan pelatihan daur ulang eceng gondok menjadi kertas dan kreasi.

Kegiatan Pendidikan dan pelatihan dilakukan secara tatap muka dengan mengikuti protokol adaptasi kebiasaan baru dalam rangka menghentikan penyebaran virus covid 19.

\section{HASIL DAN PEMBAHASAN}

\section{Diskusi Kelompok Terarah}

Progam PPDM dimulai dengan melakukan Diskusi Kelompok Terarah, adalah sebuah upaya yang sistematis dalam mengumpulan data dan informasi dengan mengedepankan 3 kata kunci yaitu diskusi (bukan wawancara atau obrolan), kelompok (bukan individu) dan fokus (bukan bebas). Dari hasil Diskusi Kelompok Terarah diketahui permasalah utama mitra yaitu dalam upaya mengurangi eceng gondok dan menambah keindahan sungai, antara lain:

a. Peserta mampu memanfaatkan eceng gondok menjadi kertas kreasi;

b. Perlunya memotivasi masyarakat agar tertarik menjadi perserta dan bisa mengolah eceng gondok menjadi kertas mengingat kurangnya sumber daya manusia;

c. Peserta baru perlu dididik dan dilatih untuk bisa mengolah eceng gondok menjadi kertas tingkat dasar;

d. Kurangnya keterampilan untuk peserta yang ada dalam mengembangkan kertas eceng gondok menjadi produk kreasi yang lebih bervariasi dan bernilai jual tinggi; e. Proses pembuatan kertas eceng gondok terhambat saat musim hujan karena tidak bisa melakukan penjemuran karena masih mengandalkan matahari;

f. Perlu teknologi pengganti matahari utuk proses penjemuran.

g. Masih belum baiknya manajemen produksi pada pengolahan eceng gondok jadi kertas kreasi;

h. Masih perlu pengembangan pemasaran, penjualan produk hasil kertas kreasi eceng gondok

Desa Lok Baintan merupakan desa yang bukan masuk katagori Zona merah ataupun hitam sehingga kegiatan diskusi kelompok terarah dilakukan dengan tatap muka dengan mengikuti protokol adaptasi kebiasaan baru dalam upaya memutus penyebaran covid 19. Hasil dari Diskusi Kelompok Terarah adalah jadwal kegiatan yang dilakukan pada tanggal 29 Juni 2020 sampai dengan 12 Juli 2020 di Desa Lok Baintan, perlunya teknologi pengganti matahari yaitu oven kertas kreasi, narasumber pakar kertas kreasi daur ulang, dengan jumlah peserta pendidikan dan pelatihan adalah 30 orang. Diskusi ini dihadiri dan disepakati oleh Kepala Desa, Ketua Karang Taruna, Ketua PKK, tokoh masyarakat dan undangan.

\section{Pemberdayaan}

Pemberdayaan menurut Kartasasmita (1995:

95) adalah upaya memberdayakan masyarakat harus dilakukan, antara lain:

Pertama adalah menciptakan suasana atau iklim yang memungkinkan potensi masyarakat untuk berkembang. Masyarakat Desa Lok Baintan memiliki kemampuan yang baik dalam menerima ilmu baru. Terbukti peserta masih konsisten memproduksi kertas eceng gondok. Proses pemberdayaan masyarakat berakar kuat pada proses kemandirian tiap individu, untuk itu pada langkah awal peserta diberikan motivasi untuk menjadi wirausaha khsususnya produk olahan eceng gondok, harapannya semangat individu dapat meluas ke keluarga, serta kelompok masyarakat baik ditingkat lokal maupun nasional.

Kedua dengan memperkuat potensi atau daya yang dimiliki oleh masyarakat dengan menerapkan langkah-langkah nyata. Dalam diskusi kelompok terarah dibuka untuk menampung berbagai masukan, menerima keluhan masyarakat dan mencari solusi secara bersama. Desa Lok Baintan memiliki potensi dengan keberadaan eceng gondok sebagai bahan utama inovasi kertas kreasi dibantu dengan adanya Pasar Terapung menjadi wadah pemasaran yang ada dilingkungan Lok Baintan. Kehadiran Program Pengambangan Desa Mitra membentuk akses peluang yang membuat 
Lewat Inovasi Eceng Gondok Menjadi Kertas Kreasi

masyarakat makin berdaya dengan tersedianya pendidikan dan pelatihan hingga pemasaran. Dalam upaya pemberdayaan masyarakat ini yang penting antara lain adalah peningkatan mutu peningkatan keterampilan melalui pelatihan dan pendidikan, serta akses pada sumber-sumber kemajuan ekonomi seperti modal dan teknologi.

\section{Pelatihan dan Pendidikan Berkelanjutan}

Menurut Aronson, Bostic, Huck, \& Rownsen (2014), ada tiga komponen yang harus dilalui dalam pelatihan kontinum relationship. Ketiga komponen itu adalah masukan (input), proses dan keluaran (output). Kegiatan pemanfaatan eceng gondok berbasis keberlanjutan dilakukan oleh masyarakat sekitaran sungai di Desa Lok Baintan dengan inovasi kreatifitas, desiminasi, manajemen, dan pemasaran sebagai fundamentalnya.

Mengubah eceng gondok menjadi kertas kreasi merupakan lanjutan dari proses pembuatan kertas sebagai salah satu solusi mengurangi sampah eceng gondok. Pengurangan eceng gondok ini dilakukan dalam rangka meningkatkan pereokonomian masyarakat di masa pandemik di saat berkurangnya wisatawan asing dan lokal di pasar terapung Lok Baintan. Kegiatan dilakukan di 29 Juni 2020 sampai dengan 12 Juli 2020 di Desa Lok Baintan dengan rincian sebagai berikut:

\section{Masukan (input)}

Peserta Program Pengembangan Desa mitra diberikan Pendidikan dan pelatihan antara lain:

i. Pendidikan Kesadaran masyarkat-Peningkatan kesadaran akan pentingnya menjaga kebersihan sungai Martapura;

ii. Pendidikan Motivasi-Menjadi Wirausaha Olahan Kreatif Pilihan Meraih Keuntungan Saat Pandemi;

iii. Pendidikan Manajemen-Manajemen Produksi Untuk Peningkatan Kuantitas dan Kualitas Produksi;

iv. Pendidikan Komunikasi Pemasaran: Strategi Bauran Pemasaran Dalam Upaya Menjadikan Produk Lokal makin Terkenal;

v. Pelatihan-Pengolahan Eceng Gondok Tingkat Mahir: Menjadi Kertas Kreasi (Produksi, kreasi, dan mewarnai);

vi. Pelatihan-Penggunaan oven Pengering Kertas Kreasi.

\section{Proses (process)}

Merupakan proses pendampingan dari tahap pengenalan hingga tahap produksi:

i. Tahap pengenalan: pengenalan bahan-bahan yaitu eceng gondok, lem fox, sampah kertas, sampah kardus, sampah plastik, clear cat dan air.
Pengenalan alat: mesin pencacah, blender, rakel, papan cetak, bak besar, oven pengering

ii. Tahap pembuatan kertas dari eceng gondok; Eceng gondok dan sampah plastik di cacah pada mesin pencacah.

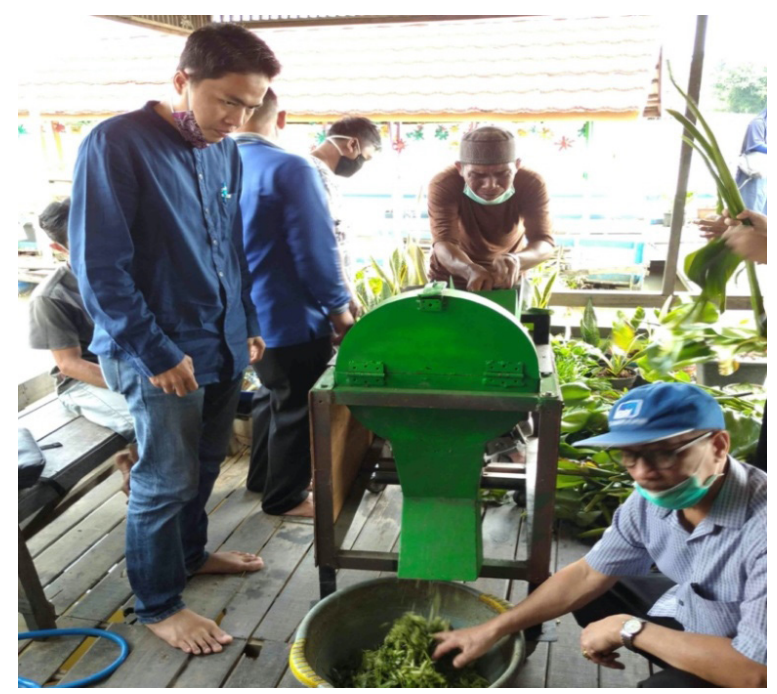

Gambar 1. Mesin Pencacah Eceng Gondok

Selanjutnya di haluskan dengan diblender sehingga jadi bubur, lalu di cetak dan dikeringkan dengan mesin oven pengering kertas.

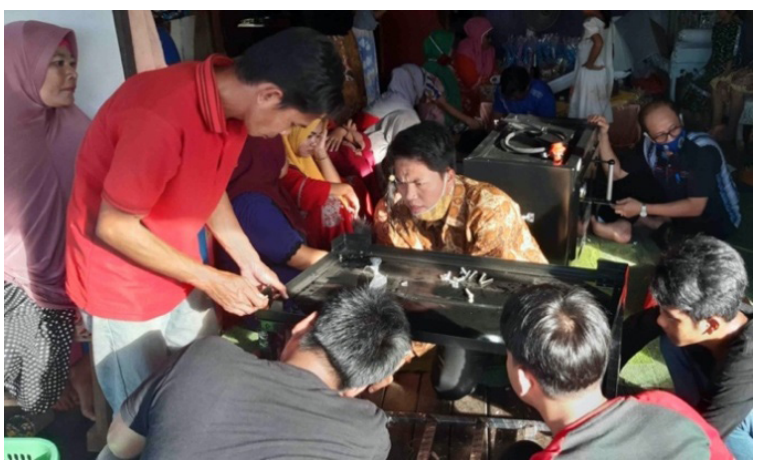

Gambar 2. Mesin Oven Pengering Kertas

i. Tahap pembuatan kertas kreasi; hasil kertas dari eceng gondok dibuat menjadi kertas kreasi.

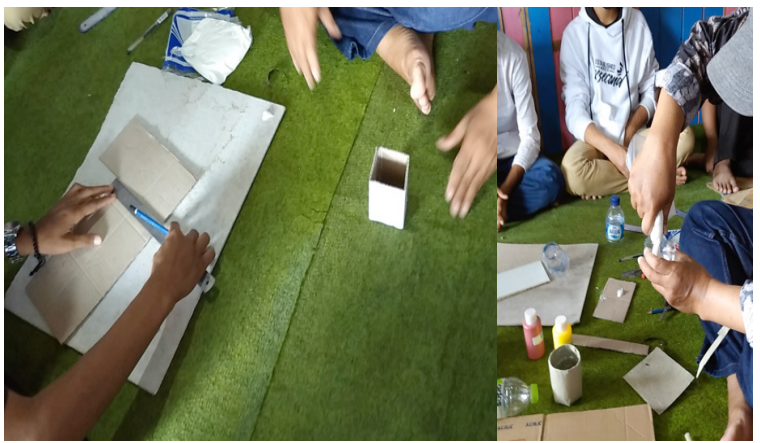

Gambar 3. Pembuatan Kreasi Kertas

ii. Tahap mewarnai: tahap akhir dalam produksi kertas kreasi dari eceng gondok, yaitu memberikan warna pada produk kreasi. 


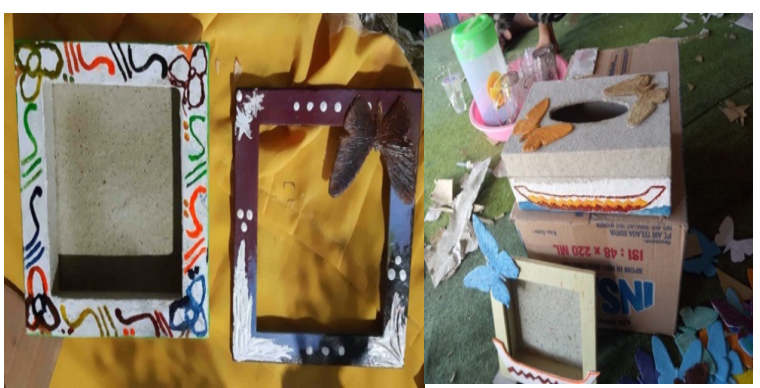

Gambar 4. Pewarnaan Kreasi Kertas

\section{a. Luaran (output)}

Produk pengolahan eceng gondok dalam kegiatan ini adalah kertas kreasi dengan hasil seperti hiasan dinding figura kupu-kupu, tempat tisu, tempat alat tulis, dan hiasan kupu-kupu (Gambar 8). Produk ini diharapkan mampu meningkatkan ekonomi kreatif masyarakat desa Lok Baintan Kalimantan Selatan dan meningkatkan kesejahteraan dimasa pandemik.

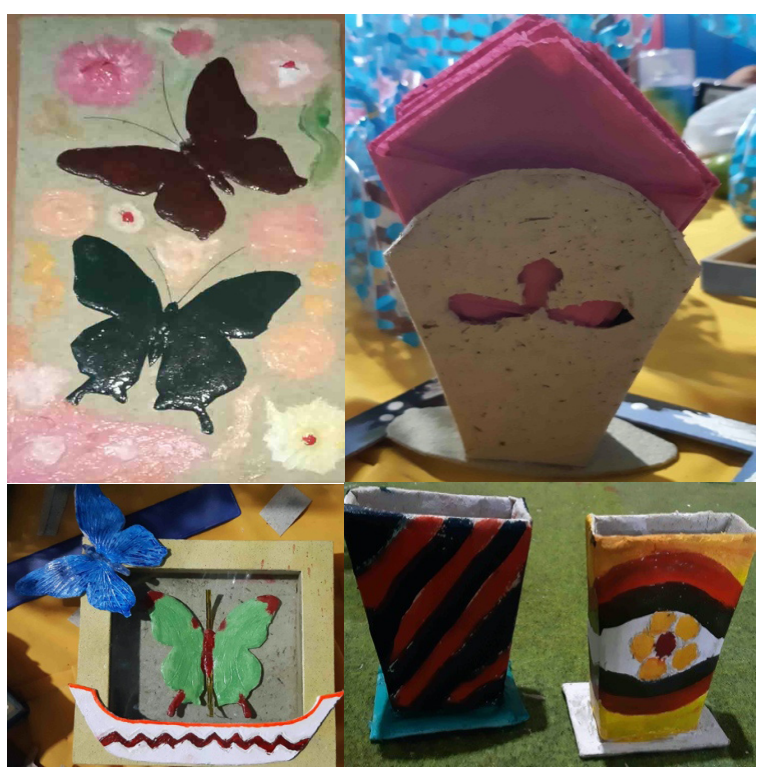

Gambar 5. Produk Hasil Kreasi Kertas

Selain produk, luaran dari kegiatan ini adalah Galeri Kreasi Ilung (gambar 9), "Ilung" merupakan bahasa lokal yang artinya Eceng Gondok. Galeri tersebut merupakan sarana penjualan sacara offline.

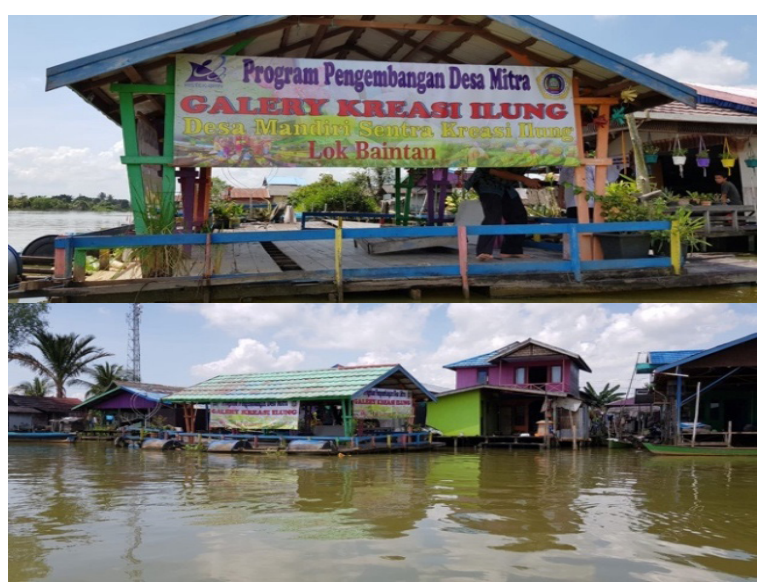

Gambar 6. Galeri Kreasi Ilung
Galeri dibuat diatas sungai Martapura dekat dengan Pasar Terapung, Desa Lok Baintan.

\section{SIMPULAN}

Program Pengembangan Desa Mitra di Desa Wisata Lok Baintan melalui pemberdayaan masyarakat Desa Sahabat Sampah, yang fokus pada pemanfaatkan eceng gondok menjadi kertas kreasi di nilai efektif dan bermanfaat bagi masyarakat Desa Lok Baintan khususnya para peserta. Pada masa pandemik seperti ini program ini menjadi alternatif dalam meningkatkan kesejahteraan peserta. Inovasi yang diiringi dengan teknologi seperti mesin pencacah dan mesin oven pengering kertas kreasi mampu meningkat produktifitas kertas kreasi eceng gondok. Peningkatan peserta diiringi dengan manajemen yang baik serta kemampuan pemasaran produk diharapkan mampu meningkatkan kualitas SDM dan produksi.

Program pengabdian kepada masyarakat melalui program Pengembangan Desa Mitra diharapkan mengurangi eceng gondok, sampah plastik, sampah kertas dan sampah kardus di sungai Martapura khusunya sekitar Desa Lok Baintan. Keberadaan Galeri diharapkan mampu menjadi daya tarik wisatawan asing maupun lokal untuk membeli produk kertas kreasi eceng gondok.

\section{UCAPAN TERIMAKASIH}

Kegiatan pengadian kepada masyarakat ini didanai oleh Kementerian Riset dan Teknologi/Badan Riset dan Inovasi Nasional, Deputi Bidang Penguatan Riset dan Pengembangan melalui Program Pengembangan Desa Mitra. Program kepada masyarakat didukung juga oleh beberapa pihak antara lain; LPPM Universitas Islam Kalimantan (Uniska) Muhammad Arsyad Al Banjari, mahasiswa yang terlibat, Bapak Sapriansyah, S.Ag. selaku Kepala Desa, Ibu Herna Rusnawati selaku ketua PKK, dan masyarakat Desa Lok Baintan. Atas dukungan dan kerjasamanya Penulis mengucapkan banyak terima kasih pada pihak-pihak terkait diatas.

\section{DAFTAR PUSTAKA}

Aronson, D., Bostic, R., Huck, Rownsed, R. (2014). Continuum Relationship and Small Business Use. Of Market. J. Urban econ, (55), 46-67.

Brem, A., Maier, M., \& Wimschneider, C. (2016). Competitive Advantage Through Innovation: the Case of Nespresso. European Journal of Innovation Management, 19(1), 133-148. https://doi.org/10.1108/EJIM-05-2014-0055 
Kartasasmita, G. (1995). Pemberdayaan Masyarakat:

Konsep yang mengakar pada masyarakat. Jakarta: Rieke Cipta.

Sutapa, Mulyana, \& Wasitowati. (2017). The Role of Market Orientation, Creativity and Innovation in Creating Competitive Advantages and Creative Industry Performance. Jurnal
Dinamika Manajemen, 8(2), 152-166. https:// doi.org/10.15294/jdm.v8i2.12756

Rodríguez-pose, A., \& Lee, N. (2013). Creativity, Cities and Innovation: Evidence from UK SMEs (10 No. 13). Retrieved from https:// pdfs.semanticscholar.org/9b1a/01cf50f8764 22aafcf75b9f583fc8386b 2f6.pdf 